\title{
Analysis of the Information Disclosure of Commercial Banks' Internal Control
}

\author{
Fangliang Huang ${ }^{1}$, Jing $\mathrm{Chen}^{1}$, Hui $\mathrm{Ma}^{2} \&$ Qiaoping $\mathrm{Hou}^{1}$ \\ ${ }^{1}$ Capital Management Research Institute, School of Finance, Shandong University of Finance and Economics, \\ China \\ ${ }^{2}$ The Industrial and Commercial Bank of China, China \\ Correspondence: Fangliang Huang, School of Finance, Shandong University of Economics and Finance, \\ Shungeng Road 40, Jinan, Shandong Province, P. R. China. Tel: 86-531-8291-1084. E-mail: \\ flhuang@sdufe.edu.cn
}

Received: March 8, 2017

Accepted: March 30, 2017

Online Published: April 15, 2017

doi:10.5539/ijef.v9n5p77

URL: https://doi.org/10.5539/ijef.v9n5p77

\begin{abstract}
By adopting the content analysis approach, this paper selects the annual reports of 45 China's commercial banks to analyze the influencing factors of internal control information disclosure. The quality of internal control information disclosure of listed banks tends to be better than non-listed banks. Our empirical study shows that the factors of the exchanges of the banks' listing, the proportion of the number of independent directors in the board of directors, and the times of the audit committee meetings have a significant positive impact on the quality of internal control information disclosure of commercial banks. To improve the quality of the internal control information disclosure of commercial banks, we put forward such suggestions as amending the supervision system, reducing the listing threshold and creating opportunities for listing for small and medium sized commercial banks, developing voluntary disclosure incentive policies, and intensifying effective punishment measures against and misbehavior in the information disclosure.
\end{abstract}

Keywords: commercial banks, internal control, information disclosure, content analysis

\section{Introduction}

The idea of internal control was introduced into China's commercial banks about 30 years ago. Some rules have gradually been issued to guide the internal control information disclosure. China Banking Regulatory Commission (CBRC) has promulgated the "Guideline for Internal Control of Commercial Banks" and the "Measures for the Information Disclosure of Commercial Banks". China Securities Regulatory Commission (CSRC) has promulgated the "Administrative Measures for the Information Disclosure of Listed Companies". Shanghai and Shenzhen Stock Exchanges and some other agencies have made internal control standards. These rules require that the information disclosed should include both voluntary and mandatory contents and the contents should be more complete and specific. It reveals that China has realized that the public supervision's effect caused by information disclosure is helpful in companies' internal control construction, implementation, and evaluation. The Ministry of Finance issued "Finance Council [2012] 30 No. 1" in August 2012 which requires China's listed banks to disclose internal control evaluation reports and audit reports in their annual reports. Although the document has no mandatory requirement for non-listed banks, as an important part of China's financial system, non-listed banks are also required to follow internal control rules. Since the "Enterprise Internal Control Basic Standards" and supporting guidelines have been released for several years, the Ministry of Finance has done research on the internal control implementation of listed companies. CBRS has also started to revise "Guidelines for Internal Control of Commercial Banks" to adapt to the more complex business environment of the banking industry.

From the different rules issued by all the related government agencies in China, we can see that the issue of the internal control information disclosure of China's commercial banks has drawn much attention in the past several years., With this background, this paper analyzes the quality of internal control information disclosure of China's commercial banks, both listed and non-listed, from the aspect of the present situation and the related influencing factors, and puts forward some suggestions for the improvement of the internal control information disclosure of China' commercial banks. 


\section{Literature Review}

In terms of the present situation of the internal control information disclosure, $\mathrm{He}, \mathrm{Li}$, and $\mathrm{Ma}$ (2003) made an investigation of the annual reports of China's listed companies. They found that only a few sample companies disclosed internal control information effectively. The sample companies barely reached the regulatory requirements, and they all had a low level voluntary disclosure. Li and Wang (2004) pointed out that the listed banks disclosed few substantive contents about the internal control information. The disclosure format was not in a unified style. Through the study of the annual reports of China' listed banks, Diao (2013) found that the disclosure had many problems such as focusing on superficial forms rather than substantial contents. Through analyzing the present situation of internal control information disclosure of listed banks, Wang (2011) studied the listed companies' information disclosure and got the same conclusion.

In terms of the influencing factors of the internal control information disclosure, Ragahunandan (1994) argued that the quality of the disclosure was positively related to the companies' performance. The lower the level of company performance was, the less willing was it to disclose internal control information. McMullen and Reghunandan (1996) found that the quality of the disclosure was positively related to the level of financial reports. The companies which had low quality of financial reports took the disclosure less serious. Ashbaugh-Skaife, Collins, and Kinney (2005), and Ge and McVay (2005) believed that the quality of disclosure was negatively related to the rate of the auditor's resignation, while positively correlated with company size and its profitability. Through studying the influencing factors of the listed companies' internal control defects between 1994 and 2000, Krishnan (2011) found that audit quality was an important factors affecting the company internal control defects. The higher the audit quality of the company was, the lower defect rate of the internal control became. The more independent the audit team was, the lower possibility of internal control defects became. Tong (2013), using the factor analysis method to study the determinants, found that the growth rate of total assets of commercial banks, the meeting times of the board of directors, the year of the listing and the ration of the capital adequacy, had significant effect on internal control information disclosure of commercial banks. Liu (2015) found that the bank size, the location of the banks, and the capital security, had profound impact on the quality of the internal control information disclosure.

Through the above previous literature, we find that there are a number of studies on the present situation and influencing factors of internal control information disclosure of listed banks, while the studies on non-listed banks' is still inadequate in China. Although the internal control disclosure rules should be obeyed by the entire banking industry, the implementation of the rules is not good enough due to the lack of strong and effective supervision. Moreover, the frequency of problems occurs among non-listed banks is very high, which exposed that there is a big lag of the non-listed banks' internal control construction. So, it is important to conduct an analysis on the present situation and influencing factors of the whole commercial banking industry.

\section{The Situation of Banks' Internal Control Information Disclosure}

The internal control standard rules were completed in 2010, only several years ago. These rules work as the base for internal control information disclosure of China's commercial banks. For listed banks, rules are issued by CBRC, CSRC and Ministry of Finance. For non-listed banks, rules are issued by CBRC and Ministry of Finance. We mainly study the forms and the contents of internal control information disclosure of to understand the present situation of the quality of internal control information disclosure.

\subsection{The Forms of Commercial Banks' Internal Control Information Disclosure}

From the 2013 annual reports of sample banks, we can tell that the forms of the internal control information disclosure are still of great variety and diversity especially for listed banks. With the gradual improvement of China's internal control rules, the supervision system of the relevant internal control information disclosure will also be gradually improved. The trend of the disclosure forms will be standardized. We select 10 kinds of forms including the internal control self-assessment reports, the internal control audit reports, and the social responsibility reports (Note 1).

Twenty-two sample banks, including all listed banks, disclosed the self-assessment reports. Listed banks followed the mandatory requirements of the Ministry of Finance and other relevant government departments disclosed the self-assessment reports while non-listed banks disclosed it voluntarily. In the self-assessment reports, listed banks and non-listed banks basically follow the same format, however, the former are more in detail than the latter.

Eighteen sample banks, including all listed banks, disclosed the audit reports. The audit reports disclosed are almost unanimously similar in contents. 
Thirty-four sample banks, including all listed banks, disclosed the social responsibility reports. In the sample banks, some disclosed the reports separately, such as the majority of listed banks. Some disclosure is embedded in the text of the annual reports.

Forty-one sample banks, including 15 listed banks, disclosed the board of directors reports. 28 sample banks, including 6 listed banks, disclosed the board of supervisors reports. Since the board of supervisors reports are removed from the latest annual reports compiling rules, there are only a small number of listed banks which disclosed this part.

Forty-one sample banks, including all listed banks, disclosed the corporate governance reports. 17 sample banks, including 7 listed banks, disclosed management discussion and analysis reports. Since corporate governance reports are also removed from the latest annual reports compiling rules, so only a small number of listed banks disclosed.

The CSRC's requirements in 2012 asked listed banks to provide disclosure implementation of internal control evaluation reports and internal control audit reports and related accountability mechanisms and measures. Judging from the internal control section's implementation in 2013, we found that 20 sample banks, including 13 listed banks, disclosed it.

\subsection{The Contents of Commercial Banks' Internal Control Information Disclosure}

\subsubsection{Category A Score}

Through the statistical score of 45 sample banks, we get the statistical Table of "Category A". "Category A" is a mandatory requirement of Ministry of Finance, CBRC, CSRC and Stock Exchange in internal control standards. Higher score of Category A means better implementation in mandatory information disclosure. Category A score is shown in Table 1.

Table 1. Category A score

\begin{tabular}{lcc}
\hline Bank category & Mean & Variance \\
\hline 45 sample banks & 27 & 13.59 \\
16 listed banks & 30 & 1.86 \\
29 non-listed banks & 25.34 & 12.38 \\
\hline
\end{tabular}

Note. Out of 36 points.

Overall, the implementation performance is better for the 45 sample banks which obeyed mandatory information disclosure, but there are differences among each of them. Specifically, listed banks perform better than non-listed banks in the implementation of mandatory information disclosure.

\subsubsection{The Category B Score}

The Category B contains five elements of internal control environment, which represents the extent of voluntary disclosure of internal control information. The higher the score is, the higher the extent becomes. Category B score is shown in Table 2.

Table 2. Category B score

\begin{tabular}{|c|c|c|c|c|c|c|}
\hline & $\begin{array}{c}\text { Internal } \\
\text { control } \\
\text { environment }\end{array}$ & $\begin{array}{c}\text { Risk } \\
\text { identification } \\
\text { and assessment }\end{array}$ & $\begin{array}{l}\text { Internal } \\
\text { control } \\
\text { measures } \\
\end{array}$ & $\begin{array}{c}\text { Information } \\
\text { communication } \\
\text { and feedback }\end{array}$ & $\begin{array}{c}\text { Supervision, } \\
\text { evaluation and } \\
\text { correction }\end{array}$ & $\begin{array}{l}\text { The total } \\
\text { score (out of } \\
64 \text { points) }\end{array}$ \\
\hline Mean of 45 sample banks & 9.35 & 5.11 & 8.75 & 5.4 & 5.2 & 33.82 \\
\hline Variance of 45 sample banks & 2.59 & 1.10 & 13.27 & 2.29 & 6.3 & 51.24 \\
\hline Mean of 16 listed banks & 10.25 & 5.75 & 9.68 & 5.43 & 7.75 & 38.87 \\
\hline Variance of 16 listed banks & 1.13 & 1.00 & 13.69 & 3.32 & 1.13 & 25.98 \\
\hline Mean of 29 non-listed banks & 8.86 & 4.75 & 8.24 & 5.37 & 3.79 & 31.03 \\
\hline Variance of 29 non-listed banks & 2.76 & 0.83 & 12.76 & 1.81 & 3.52 & 43.96 \\
\hline
\end{tabular}

As is seen in Table 2, 45 sample banks perform poorer in voluntary information disclosure, especially in the internal control measures, while in internal control environment and risk identification and assessment, listed banks and non-listed banks all perform better. The internal control environment is the general and basic element and the cost of its disclosure is low, so its disclosure is more thoroughly. Banking is an important industry which 
contains monetary operations and risk management, the risk identification and assessment disclosure is the key of the banking industry. Moreover, banking is constrained by more external mandatory requirements, so the disclosure quality of this element is ideal. However, internal control measures cover a wide range and may refer to the business secrets and the cost of disclosure is high, so it is less disclosed. As for information communication and feedback, it is relatively unimportant for the internal control, the disclosure quality of this element is also low. The supervision and evaluation and correction are lack of substantial content, so the disclosure quality of this element is low, too. In conclusion, China's commercial banks still have a lot of aspects to be standardized and unified in terms of voluntary disclosure. Relevant laws and regulations should assess the situation, add the voluntary disclosure content into the scope of mandatory disclosure gradually.

\section{The Influencing Factors of Banks' Internal Control Information Disclosure}

\subsection{Empirical Analysis}

\subsubsection{Variables Selection}

\subsubsection{The Explained Variables}

The explained variable in this paper is the quality of internal control information disclosure. Because the internal control information were published in commercial banks' various forms, and most of them are in text form, in order to facilitate our empirical research, we need to change the text data to comparable data which are in the form of quantity. This paper measures the quality of internal control information disclosure of the sample banks by using disclosure index score of content analysis.

This paper defines the ICDI as the explained variables to measure the quality of internal control information disclosure.

This paper mainly takes the reports data of the sample banks in 2013 as the research subject, including annual reports, audit reports, internal control evaluation reports, internal control audit reports, social responsibility reports and so on. In accordance with the internal control information disclosure index item list in which the category is defined, this paper adopts the method of item-by-item assignment category score, and eventually gets the sample banks' ICDI which is shown in Table 3.

Table 3. ICDI score

\begin{tabular}{lc}
\hline Bank name & ICDI \\
\hline Ping An Bank & 62 \\
Bank of Ningbo & 72 \\
Bank of Nanjing & 76 \\
Bank of Beijing & 68 \\
China Everbright Bank & 61 \\
Huaxia Bank & 65 \\
SPD Bank & 66 \\
China Minsheng Banking Corp & 72 \\
China Merchants Bank & 63 \\
Industrial Bank & 75 \\
CITIC Bank & 68 \\
ICBC & 77 \\
Bank of China & 70 \\
Bank of Communications & 66 \\
China Construction Bank & 68 \\
Agricultural Bank of China & 73 \\
CGB & 59 \\
Zheshang Bank & 54 \\
Bohai Bank & 43 \\
Evergrowing Bank & 57 \\
Bank of Shanghai & 64 \\
Bank of Jiangsu & 51 \\
Huishang Bank & 59 \\
Bank of Tianjin & 69 \\
Bank of Hangzhou & 5 \\
\hline
\end{tabular}




\begin{tabular}{ll}
\hline Bank of Dalian & 54 \\
Bank of Guangzhou & 53 \\
Bank of Chengdu & 56 \\
Bank of Jilin & 49 \\
Bank of Haerbin & 59 \\
Bank of Baoshang & 56 \\
Bank of Chongqing & 58 \\
Bank of Dongguan & 61 \\
Bank of Hankou & 64 \\
Qilu Bank & 37 \\
Bank of Xi'an & 47 \\
Fudian Bank & 60 \\
Bank of Hebei & 59 \\
Bank of Qingdao & 45 \\
Bank of Guiyang & 70 \\
Bank of Zhengzhou & 63 \\
Bank of Wenzhou & 72 \\
Zhejiang Chouzhou Commercial Bank & 50 \\
Weihai City Commercial Bank & 57 \\
Bank of Ningxia & 39 \\
\hline
\end{tabular}

\subsubsection{The Explanatory Variables}

Based on the related literature and the research results, combined with the characteristics of the sample banks, we exclude the factors which do not apply to commercial banks. After the screening, we choose five influencing factors-total assets (taking natural logarithms), the rate of non-performing loans, the proportion of the independent directors, the audit committee meeting times and domestically listed as research variables. The hypotheses are based on these factors. The specific variables are shown in Table 4.

Table 4. Specific variables

\begin{tabular}{ccll}
\hline Variable type & Variable code & Variable name & Remark \\
\hline Explained & ICDI & Internal control information disclosure index & Measure the quality of internal control information disclosure \\
& TA & Natural logarithms of total assets & Eliminate the volatility of data \\
& NPLR & The rate of non-performing loans & Equal to the actual NPLR*1000 \\
Explanatory & DL & Domestically listed & The value of listed banks is 1, or 0 \\
& PID & The proportion of independent directors & \\
& ACMT & The audit committee meeting times & \\
\hline
\end{tabular}

\subsubsection{Hypotheses}

Based on the selected explanatory variables, we put forward the following hypotheses according to the relevant theory and empirical evidence.

H1: The quality of the internal control information disclosure is positively related to bank size.

$\mathrm{H} 2$ : The quality of the internal control information disclosure is negatively related to the rate of non-performing loans.

H3: The quality of the internal control information disclosure of listed banks is better than non-listed banks.

H4: The quality of the internal control information disclosure is positively related to the proportion of independent directors.

H5: The quality of the internal control information disclosure is positively related to the audit committee meeting times.

\subsubsection{Samples and Data Resource}

Follow the principle of information availability and analytical value or statistical significance, this paper selects 28 city commercial banks from 145 city commercial banks, which disclosed the internal control information more completely, have larger asset size and have a wide-ranged business. The finally research sample include 
five large state-owned commercial banks, 12 national joint-stock commercial banks and 28 city commercial banks. The annual reports data and related data for the research are from the sample bank's official website, the Shanghai Stock Exchange website, the Shenzhen Stock Exchange website, and Juchao database.

\subsection{Model}

The data selected in this paper is cross-section data, so this paper constructs a multiple linear regression model.

$$
I C D I=\beta_{0}+\beta_{1} T A+\beta_{2} A C M T+\beta_{3} D M+\beta_{4} P I D+\beta_{5} N P L R+\varepsilon
$$

\subsection{Empirical Results}

\subsubsection{Descriptive Statistics}

\subsubsection{Descriptive Statistics Analysis}

Table 5. Descriptive statistics

\begin{tabular}{lcccccc}
\hline & Observations & Mean & Median & Max & Min & Std. Dev. \\
\hline ICDI & 45 & 60.82 & 61.00 & 79.00 & 37.00 & 9.98 \\
TA & 45 & 27.17 & 26.73 & 30.57 & 25.10 & 1.57 \\
NPLR & 45 & 8.61 & 8.70 & 19.60 & 0.30 & 3.01 \\
DL & 45 & 0.36 & 0.00 & 1.00 & 0.00 & 0.48 \\
PID & 45 & 0.33 & 0.33 & 0.46 & 0.09 & 0.07 \\
ACMT & 45 & 4.09 & 4.00 & 7.00 & 0.00 & 1.89 \\
\hline
\end{tabular}

As is seen in Table 5, the average value of ICDI is 60.82 , which means the quality of sample banks information disclosure is overall qualified. The max value of ICDI is 79 , the $\min$ is 37 and the standard deviation is 9.98 , which means great gap exists between the quality of sample banks information disclosure and implementation of the internal control system. The total assets value is 27.17 with little difference between the median 26.73 , which indicates that large banks account for a relatively small. The max value of the rate of non-performing loans is 19.60 , the min is 0.30 and the standard deviation is 3.01, which means great difference among sample banks, moreover, the rate of some banks is exceeded the warning level which means great attention need to be paid to risk prevention. The max value of the proportion of independent directors is 0.46 , the average is 0.46 , the standard deviation is 0.07 , which means it is in line with the Company Law and some are greater than the minimum standards of Company Law. The average value of the audit committee meeting times is 4.09 , which means it is in line with the Company Law, the max is 7 , the mix is 0 , and the standard deviation is 1.89 , it reveals that there are some differences in the number of audit committee meetings, and some banks did not hold the audit committee in 2013.

\subsubsection{Joint Analysis of Explanatory Variables and Explanatory Variables}

Table 6. Joint analysis

\begin{tabular}{lcccccc}
\hline Correlation matrix & ICDI & TA & ACMT & DL & NPLR & PID \\
\hline ICDI & 1.000000 & 0.544872 & 0.651716 & 0.606244 & 0.175408 & 0.428041 \\
TA & 0.544872 & 1.000000 & 0.571874 & 0.817394 & 0.147483 & 0.155312 \\
ACMT & 0.651716 & 0.571874 & 1.000000 & 0.546977 & 0.260561 & 0.393368 \\
DL & 0.606244 & 0.817394 & 0.546977 & 1.000000 & 0.106070 & 0.288764 \\
NPLR & 0.175408 & 0.147483 & 0.260561 & 0.106070 & 1.000000 & 0.022144 \\
PID & 0.428041 & 0.155312 & 0.393368 & 0.288764 & 0.022144 & 1.000000 \\
\hline
\end{tabular}

Table 6 shows the correlation matrix between the explained variable and explanatory variables. As seen in Table 6 , the correlation between ICDI and NPLR is poor, so, NPLR might not be significant in model (1). The correlation between ICDI and ACMT, DL is ideal, so, the two explanatory variables may be significant stronger in model (1). The correlation between ICDI and TA, PID is general, so, the two explanatory variables may be significant at a confidence level.

\subsubsection{Model Regression}

4.2.2.1 Preliminary Regression and Results

1) Input explained and explanatory variables into EViews3.1. The regression results are shown in Table 7. 
Table 7. Regression results

\begin{tabular}{|c|c|c|c|c|}
\hline Variable & Coefficient & Std. Error & t-Statistic & Prob. \\
\hline $\mathrm{C}$ & 32.48296 & 34.26146 & 0.948090 & 0.3489 \\
\hline $\mathrm{TA}$ & 0.286446 & 1.274661 & 0.224723 & 0.8234 \\
\hline ACMT & 2.200639 & 0.859011 & 2.561829 & 0.0144 \\
\hline DL & 6.314998 & 4.063586 & 1.554046 & 0.1283 \\
\hline PID & 25.08902 & 16.76760 & 1.496280 & 0.1426 \\
\hline NPLR & 0.112380 & 0.374919 & 0.299744 & 0.7660 \\
\hline R-squared & 0.540705 & \multicolumn{2}{|c|}{ Mean dependent var } & 60.82222 \\
\hline Adjusted R-squared & 0.481821 & \multicolumn{2}{|c|}{ S.D. dependent var } & 9.977905 \\
\hline S.E. of regreDMion & 7.182559 & \multicolumn{2}{|c|}{ Akaike info criterion } & 6.904754 \\
\hline Sum squared resid & 2011.977 & \multicolumn{2}{|c|}{ Schwarz criterion } & 7.145643 \\
\hline Log likelihood & -149.3570 & \multicolumn{2}{|c|}{ F-statistic } & 9.182552 \\
\hline Durbin-Watson stat & 2.138744 & \multicolumn{2}{|c|}{ Prob(F-statistic) } & 0.000008 \\
\hline
\end{tabular}

As seen in Table 7, model (1) has a better goodness of fit and significance which is at a confidence level (0.01), which means the explained variable in the model is well explained by the overall explanatory variables. TA and NPLR to ICDI are not significant, that means assets and non-performing loan ratio have no effect on the internal control information disclosure. ACMT is significant at a confidence level (0.01). It shows that the audit committee meeting times has a significant impact on the quality of internal control information disclosure and the more times of audit committee meetings, the higher quality of the internal control information disclosure. DM and PID are significant at a lower confidence, which means domestically listed as well as the proportion of independent directors has little influence on the quality of internal control information disclosure. If the proportion of independent directors is improved or the number of listed banks is increased, the quality of internal control information disclosure will be improved to a certain extent.

2) Multicollinearity

We use the test method of correlation coefficient to examine whether multicollinearity problems exist among the explanatory variables in model (1). From Table 6, we can see that the correlation coefficient between DL and TA is 0.82 , so, multicollinearity problems exist.

\subsubsection{Adjust Regression and Results}

From the above, we know that TA and NPLR have no effect on ICDI, also, multicollinearity problems exist between TA and DL. So, TA and NPLR were removed from model (1). The reconstructed model is as follows:

$$
I C D I=\alpha_{0}+\alpha_{1} A C M T+\alpha_{2} D M+\alpha_{3} P I D+\varepsilon
$$

1) Input explanatory and explained variable into EViews3.1. The regression results are shown in Table 8.

Table 8. Regression results

\begin{tabular}{|c|c|c|c|c|}
\hline Variable & Coefficient & Std. Error & t-Statistic & Prob. \\
\hline $\mathrm{C}$ & 40.94319 & 5.134027 & 7.974867 & 0.0000 \\
\hline DL & 6.970048 & 2.622768 & 2.657516 & 0.0112 \\
\hline PID & 23.76068 & 15.85308 & 1.498806 & 0.1416 \\
\hline ACMT & 2.323639 & 0.772774 & 3.006880 & 0.0045 \\
\hline R-squared & 0.539010 & \multicolumn{2}{|c|}{ Mean dependent var } & 60.82222 \\
\hline Adjusted R-squared & 0.505279 & \multicolumn{2}{|c|}{ S.D. dependent var } & 9.977905 \\
\hline S.E. of regreDMion & 7.018101 & \multicolumn{2}{|c|}{ Akaike info criterion } & 6.819550 \\
\hline Sum squared resid & 2019.404 & \multicolumn{2}{|c|}{ Schwarz criterion } & 6.980142 \\
\hline Log likelihood & -149.4399 & \multicolumn{2}{|c|}{ F-statistic } & 15.97966 \\
\hline Durbin-Watson stat & 2.117834 & \multicolumn{2}{|c|}{ Prob(F-statistic) } & 0.000000 \\
\hline
\end{tabular}

As seen in Table 9, the model (2) has a certain degree of improvement compared with model (1) in the goodness of fit and the significance, not only the overall variables but each of explanatory variables. That means the audit committee meeting times, domestically listed, and the proportion of independent directors have more credible explanation ability on the quality of internal control information disclosure. 


\section{2) Multicollinearity}

We use correlation coefficient test method to examine whether multicollinearity problems exist among the explanatory variables in model (2). The correlation coefficient among the explanatory variables is less than 0.8 , So, it can be considered that no multicollinearity problems exist.

\section{3) Heteroscedasticity}

We use residual graphical analysis method to test whether heteroscedasticity problem exists in model (2).

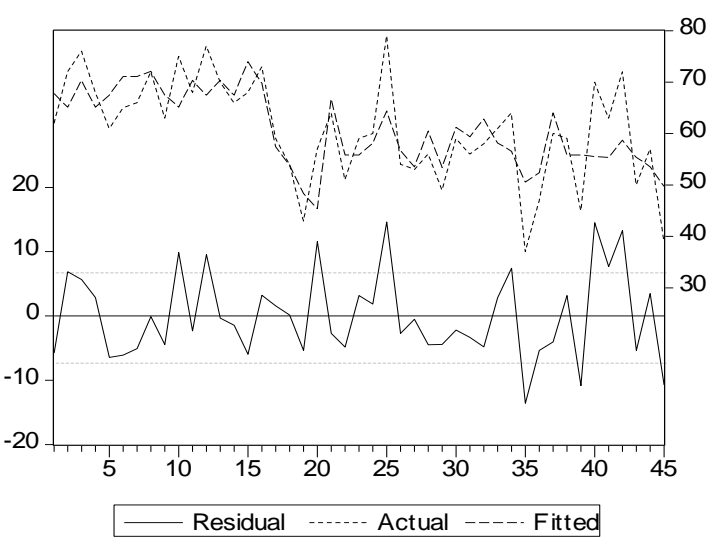

Figure 1. Heteroscedasticity inspection

As seen in Figure 1, the residual does not change with the change of the explanatory variables in model (2). So, it can be considered that there is no heteroscedasticity.

\section{4) Autocorrelation}

We use DW test method to test whether autocorrelation problem exists in residual. As is seen in Table 8, the DW value is 2.12 . When $\mathrm{n}$ equals $45, \mathrm{p}$ equals 3 , the critical value $\mathrm{dl}$ equals 1.383 , du equals 1.666 . It can be concluded that there is no autocorrelation problem in model (2). In other words, no important explanatory variables are missing in model (2).

\subsubsection{Regression Results Analysis}

\section{1) Asset Size}

We adopt the natural logarithm of total assets as the measurement variable of sample banks size. The quality of internal control information disclosure is positively related to the bank size as can be seen from model (1), which is consistent with the hypothesis 1 , while the variable is not significant and in conflict with previous research results. It was found that some small banks have a better quality of internal control information disclosure, such as bank of Zhejiang and Wenzhou, while the quality of internal control information disclosure of some banks with large assets is not high, such as China Everbright Bank and Pingan Bank.

\section{2) Asset Quality}

We adopt the non-performing loan ratio as the measurement variable of sample banks' asset quality. The regression results of model (1) are in conflict with hypothesis 2 and the variable is not significant. Judging from the relevance between ICDI and NPLR, we can see that the correlation coefficient is very small. So, non-performing loans do not have the interpretation ability for influencing the quality of internal control information disclosure.

\section{3) Corporate Governance}

This article selects the proportion of independent directors and the audit committee meeting times as corporate governance variables for the model. The regression results of model (2) are consistent with the hypothesis 4 and hypothesis 5 , and the explanatory of the two variables are more significant. The audit committee meeting times has a strong ability to explain the quality of internal control information disclosure.

\section{4) Domestically Listed Banks}

The regression results of model (2) is consistent with the hypothesis 3, which shows that in China, being listed or not has a certain influence on the quality of commercial banks' internal control information disclosure. Listed 
banks are strictly regulated by the CSRC and Stock Exchanges. Naturally, the internal control information disclosure will show relatively better. On the other hand, more complete disclosure on internal control information can help domestically listed banks win the public's trust, and thereby improve their ability to refinance.

\section{Conclusions and Suggestions}

By analyzing the present situation of internal control information disclosure of commercial banks, this paper finds that listed banks perform better than non-listed banks in the quality of disclosure. In terms of disclosure forms, the bases of disclosure are gradually of convergence and the forms of the disclosure are still of great variety and diversity. In terms of disclosure contents, commercial banks' mandatory disclosure is better than voluntary disclosure. Through the empirical analysis of the influencing factors of internal control information disclosure of commercial banks, this paper finds that the proportion of independent directors and the audit committee meeting times have significant positive impacts on the quality of internal control information disclosure of commercial banks. Getting listed or not also has a significant impact on the disclosure quality and being listed can improve the disclosure quality significantly while asset size and asset quality have no significant impact on the disclosure quality.

To prevent the risk of commercial banks' operating decisions and enhance commercial banks' competitiveness under the impact of competitive internet banking, we put forward suggestions from two aspects of internal management and external supervision of commercial banks. In their internal management commercial banks should improve the construction of management mechanism, effectively carry out the responsibility of independent directors and audit committee. The government should reduce lower the listing threshold and encourage IPOs for small and medium commercial banks. Voluntary disclosure incentive policies should be made to boost the enthusiasm of the commercial banks to carry on the voluntary disclosure. It is necessary to strengthen substantive audit of the quality of internal control information disclosure of commercial banks and intensify punishment for those banks who only meet the requirements superficially.

Due to the limited number of sample commercial banks available, one major shortcoming of this paper is that we have not set the control variables to distinguish different types of bank characteristics. When there are more sample banks in the future, further research may examine the related issues of different type of banks (five large state-owned, national joint-stock and city commercial banks) to see if there will be different empirical results.

\section{Acknowledgments}

We gratefully acknowledge the financial support of China's National Social Science Fund Key Project "Study of the IPO Information Disclosure and Investors' Protection" (15AJY019). We thank Yang Min, Xiong Dehao, Li Lei, Wang Tongtong, Zhang Xiaobo, Qiu Hao, Feng Tianhao, Liu Ruiqi and Han Xu for their helpful comments. All errors remain our own.

\section{References}

Ashbaugh-Skaife, H., Collins, D., \& Kinney, W. (2005). The Discovery and Reporting of Internal Control Deficiencies Prior to SOX-Mandated Audits. Journal of Accounting and Economics, 44, 166-192. http://dx.doi.org/10.1016/j.jacceco.2006.10.001

Diao, X. J. (2013) The Research on Internal Control Information Disclosure of China's Listed Commercial Banks. China Futures Research, 7, 47-48. Retrieved from http://www.doc88.com/p-9045496579220.html

Ge, W., \& Mcvay, S. (2005). The Disclosure of Material Weaknesses in Internal Control after The Sarbanes-Oxley Act. Accounting Horizons, 9, 83-95. http://dx.doi.org/10.2308/acch.2005.19.3.137

He, H., Li, M. H., \& Ma, X. K. (2003). Analysis of Internal Control Information Disclosure of China's Listed Commercial Banks. Auditing Research, 1, 38-43. Retrieved from http://www.cnki.com.cn/Article/CJFDTOTAL-SJYZ200301008.htm

Krishnan, J. (2011). Audit Committee Quality and Internal Control: An Empirical Analysis. Accounting Review, 80(2), 649-675. http://dx.doi.org/10.2308/accr.2005.80.2.649

Li, M. H., \& Wang, X. J. (2004). The Research on Internal Control Information Disclosure of Listed Commercial Banks. Financial Research, 5, 53-63. Retrieved from http://www.cnki.com.cn/Article/CJFDTOTAL-JRYJ200405007.htm

Liu, B. H. (2015). The Research on Factors Affecting the Quality of Internal Control Information Disclosure of Listed Banks. Hebei University of Economics and Business. Retrieved from http://cdmd.cnki.com.cn/Article/CDMD-11832-1015566776.htm 
McMullen, D. A. K., \& Reghunandan. (1996). Internal Control Reports and Financial Reporting Problems. Accounting Horizons, 4, 67-75. http://dx.doi.org/15.2638/acch.1996.25.5.237

Ragahunandan, \& Rama, D. V. (1994). Management Reports after COSO. Internal Auditor, 54-59.

Tong, X. P. (2013). The Research on Factors Affecting the Quality of Internal Control Information Disclosure of China Commercial Banks. Tianjin University. Retrieved from http://cdmd.cnki.com.cn/Article/CDMD-10056-1015018726.htm

Wang, H. F. (2011). Internal Control Deficiencies Identified: Status, Dilemma and the Basic Framework of Reconstruction. Accounting Research, 8, 61-67. Retrieved from http://www.cnki.com.cn/Article/CJFDTOTAL-KJYJ201108011.htm

\section{Note}

Note 1. All these reports are publicly disclosed and are available online. We searched them through the Chinese search engine Baidu, the Wind Database, and the websites of Shanghai Stock Exchange and Shenzhen Stock Exchange.

\section{Copyrights}

Copyright for this article is retained by the author(s), with first publication rights granted to the journal.

This is an open-access article distributed under the terms and conditions of the Creative Commons Attribution license (http://creativecommons.org/licenses/by/4.0/). 